\title{
Quality Control standardization of Wild Himalayan Pear: Pyrus pashia
}

\author{
Siva Hemalatha ${ }^{1}{ }^{*}$, Priyanka Sharma ${ }^{1}$, Satyendra Kuldip Prasad ${ }^{2}$ \\ 'Department of Pharmaceutics, Indian Institute of Technology, Banaras Hindu University, Varanasi-221005, INDIA. \\ 2Department of Pharmaceutical Sciences, Rashtrakant Tukadoji Maharaj Nagpur University, INDIA.
}

\begin{abstract}
Introduction: To establish the pharmacognostical and phytochemical standardization parameters of Pyrus pashia fruits in order to ensure quality and safety of this traditionally acclaimed medicinal tree. Methods: The fresh fruits of $P$. pashia were collected and dried. Fruit was subjected to various pharmacognostical investigations, Extraction procedures, and preliminary phytochemical screening, according to WHO guidelines. Ethanolic extract was standardized to total phenolic and flavonoid content, followed by phytochemical quantification of $P$. pashia extract using lupeol as a chemical marker by HPLC method. Results: In the present study, microscopy of the fruit showed typical characteristics of berry, having thick fleshy pericarp differentiated into thin epicarp and thick mesocarp having wide radiating carpel chambers with one or two seeds attached in axile placentum. Further, physicochemical evaluation was done like, loss on drying, total ash value, acid insoluble ash value, water soluble ash value, fluorescence analysis etc. Heavy metal and pesticide residue analysis was also performed. Furthermore, ethanolic extract of Pyrus pashia (EPP) obtained from cold maceration and phytochemical screening of different fractions obtained by
\end{abstract}

liquid partitioning revealed the presence of various secondary metabolites such as glycosides, steroids, triterpenoids, phenols flavonoids etc. Moreover, the total phenolic content and total analysis revealed that fruits are rich source of phenols and flavonoid. The HPLC chromatogram suggested that EPP contained $4.24 \% \mathrm{w} / \mathrm{w}$ of lupeol. Conclusion: Pharmacognostical and phytochemical investigation will ensure quality and safety of this medicinal plant, furthermore HPLC quantification will aid in authentication and development of monograph.

Key words: Pyrus pashia, Lupeol, Standardization, Total phenolic content, Total flavonoid content, HPLC.

Corresponding author: Dr. (Mrs.) S. Hemalatha, M. Pharm, Ph.D, Associate Professor, Department of Pharmaceutics, Indian Institute of Technology, Banaras Hindu University, Varanasi-221005, INDIA.

Phone no: 0542-6702746(O).09415256481(M)

Email: shemalatha.phe@itbhu.ac.in

DOI : 10.5530/pj.2016.4.8

\section{INTRODUCTION}

Discovery of new molecules from the medicinal plants is prevailing now-a-days to treat several disorders because of fewer undesirable side effects than synthetic drugs. ${ }^{1}$ According to World Health Organization (WHO), herbal medicines are defined as plant-derived material or preparations with therapeutic or other human health benefits which contain either raw or processed ingredients from one or more plants. ${ }^{2}$ Traditional medicines are considered as first line treatment in many tribes and have potential to treat several diseases. The therapeutic potential of a medicinal plant depends on its form, parts of a plant, type of extracts and isolated active constituents. However, these traditional uses require scientific validation to be integrated into modern medicine. ${ }^{3}$ It is well accepted that plants possess multitude of phytochemicals because of inherent inconsistency and a plethora of environmental factors. ${ }^{4}$ Thus, a well defined and constant composition of the drug is therefore one of the most important criteria for the execution of its quality. Moreover, pharmacognostic study is the preliminary step in the standardization of the crude drugs in order to ensure safety and consistency. The detailed pharmacognostic evaluation provides valuable information of morphology, microscopic and physical characteristics of a crude drug. ${ }^{5}$ Hence, several quality control tests should be adopted during scientific validation for the herbal medicines to standardize the product.

The biodiversity of the Himalayan pear (Pyrus pashia Hamilton ex D. Don) family Rosaceae, is distributed across the Himalayas from Pakistan to Vietnam and from the southern provinces of China to the northern regions of India. ${ }^{6}$ It is a small to medium sized deciduous tree with small and ovate shaped toothed leaves, attractive white flowers and small pear like fruits (Figure 1A). ${ }^{7}$ Traditionally, fruits and leaf crush is used in cuts, wounds and fungal infection in Mandi district of Himachal Pradesh. ${ }^{8}$ Leaves, twigs, fruits and wood are used in treatment of mouth infection and eye complaints by the people of Mandi district Himachal Pradesh., 10 In folk medicine of Gharwal region, fruits of this plant are traditionally being used in treatment of digestive disorders. ${ }^{11}$ It is well documented that ripen fruits are considered as edible by many tribes while tender leaves and twigs are used as fodder, leaf extract is used as a tonic for hair loss and woods are used as a major fuel source in the central Himalayan region. ${ }^{12-14}$ The leaves are consumed as tea beverages by the Monpa Community of Tawang, Arunachal Pradesh (India). Twigs of the tree are popularly being used in tooth ache problems by the indigenous people of Jammu Kashmir and Laddhak divisions of India. ${ }^{16}$ Crushed fresh leaves are used as popular folk cosmetic by tribal communities of North-West Frontier Province, Pakistan for staining palms, feet and nails. ${ }^{17}$ Ripened fruits are used for treatment of constipation by tribal communities of Lesser Himalayas-Pakistan. ${ }^{18}$ Fruits are popular home remedy and are used as febrifuge, sedative and astringent in Khanbad village of Pakistan. ${ }^{19}$ Fruits are prescribed against asthma by the local vaidyas of Dronagiri, Uttaranchal. ${ }^{20}$ Experimental study suggests that it has significant antimicrobial activity against Klebsiella pneumonia, Shigella flexneri and Escherechia. Coli. ${ }^{15}$

Based on the above facts, it is considered that the fruit of this plant has divergent medicinal applications. Hence, in the present study an attempt has been made to establish standardized parameters of Pyrus pashia (P. pashia) fruits in order to ensure its quality and safety.

\section{MATERIALS AND METHODS}

\section{Plant Material}

Fruits were collected in month of June year 2015 from Pyrus pashia tree located in Dharamsala, district Kangra Himachal Pradesh $\left(32.218^{\circ} \mathrm{N}\right.$ and $76.320^{\circ} \mathrm{E}$ ). Fruit samples were authenticated by Dr. Brijlal, Senior Principal Scientist and Curator, CSIR-Institute of Himalayan Bioresource and 
Technology, Palampur, H.P. The sample has been deposited in Institutional herbarium (voucher specimen no: 16583). Fruits were dried, powdered and then were stored in an air tight container for further use.

\section{Macroscopic Study}

Morphological evaluation involves investigation of its shape, size, colour, odour and taste. Macroscopic evaluation is considered as the first step for establishing identity of a crude drug. According to WHO. ${ }^{2}$

\section{Microscopic Study}

The required samples of $P$. pashia fruit were cut and fixed in FAA (Formalin-5 ml + Acetic acid-5 ml $+70 \%$ Ethyl alcohol-90 ml). After $24 \mathrm{~h}$ of fixing, the specimens were dehydrated with graded series of Tertiary-butyl alcohol (TBA). Infiltration of the specimens was carried by gradual addition of paraffin wax (melting point $58-60^{\circ} \mathrm{C}$ ) until TBA solution attained super saturation. The specimens were then casted into paraffin blocks. The paraffin embedded specimens were sectioned with the help of Rotary Microtome. The thickness of the sections was 10-12 $\mu \mathrm{m}$. Dewaxing of the sections was by customary procedure. ${ }^{21}$ The sections were stained with Toluidine blue as per the method published by. ${ }^{22}$ Since Toluidine blue is a polychromatic stain. The staining results were remarkably good; and some cytochemical reactions were also obtained. The dye rendered pink colour to the cellulose walls, blue to the lignified cells, dark green to suberin, violet to the mucilage, blue to the protein bodies etc. wherever necessary sections were also stained with safranin and Fast-green. Powdered materials of different parts were cleared with $\mathrm{NaOH}$ and mounted in glycerine medium after staining.

Photographs of different magnifications were taken with Nikon labphoto 2 microscopic Unit. For normal observations bright field was used. For the study of crystals, starch grains and lignified cells, polarized light was employed. Since these structures have birefringent property, under polarized light they appear bright against dark background.

\section{Physico-Chemical Analysis}

Various physicochemical parameters of the powdered fruit samples such as, Loss on Drying, Total ash, Acid-insoluble ash, Water-soluble ash, Alcohol soluble extractives, Water-soluble extractable matter, Crude fiber content, were evaluated according to methods described in WHO guidelines ${ }^{2}$ and Indian Herbal Pharmacopoeia. ${ }^{23}$ Each study was performed in triplicate; mean values with standard error of mean (SEM) were calculated.

The powdered fruit was subjected to fluorescence analysis according to standard methods published by Chase and Pratt, ${ }^{24,25}$ fluorescence pattern of the solution mixture was monitored under day light as well as under ultra violet light (254 $\mathrm{nm}$ and $365 \mathrm{~nm}$ ).

\section{Quantitative determination of heavy metal and minerals}

Present study included investigation of four heavy metals viz. Lead $(\mathrm{Pb})$, mercury ( $\mathrm{Hg}$ ), zinc $(\mathrm{Zn})$ and cadmium (Cd). $2 \mathrm{~g}$ of powdered drug was digested with $10 \mathrm{~mL}$ conc. $\mathrm{HNO}_{3}$ followed by heating in a hot plate for $15 \mathrm{~min}$ at $95^{\circ} \mathrm{C}$. This process was repeated twice for another $30 \mathrm{~min}$ until the red fumes of nitric acid disappeared. The solution was cooled and $2 \mathrm{~mL}$ of deionized water and $3 \mathrm{~mL}$ hydrogen peroxide (30\% v/v) was added to start the peroxide reaction. After the reaction was completed, $5 \mathrm{~mL}$ of conc. $\mathrm{HCl}$ and $10 \mathrm{~mL}$ deionized water was added and the samples were heated for an additional $15 \mathrm{~min}$. The sample was cooled, filtered and volume was made up to $50 \mathrm{ml}$. The estimation of heavy metals was analyzed by using atomic absorption spectroscopy (Shimadzu-AA6300). ${ }^{26}$
The results obtained were expressed in terms of parts per million (PPM) per gram of drug.

\section{Evaluation of Pesticide content}

The pesticide content analysis of the fruits was performed according to the WHO guideline. ${ }^{2} 350 \mathrm{~mL}$ of acetonitrile: water (65:35) was added to $50 \mathrm{~g}$ of grinded powdered fruits and was blended at high speed for $5 \mathrm{~min}$ followed by filtration. $250 \mathrm{~mL}$ of filtrate was transferred to a separating funnel to which further $100 \mathrm{~mL}$ light petroleum, $10 \mathrm{~mL}$ of sodium chloride (40\%) and $600 \mathrm{~mL}$ of water were added with constant shaking up to $35-45 \mathrm{sec}$. Organic solvent layer was washed twice with $100 \mathrm{~mL}$ portions of water to which $15 \mathrm{~g}$ of anhydrous sodium sulphate was added with vigorous shaking. The separated extract was then reduced to 5 to $10 \mathrm{~mL}$ volume which was subjected to column packed with Florisil $\mathrm{R}$ grade $60 / 100 \mathrm{PR}$, activated at $650^{\circ} \mathrm{C}$ maintaining a rate of not more than $5 \mathrm{~mL} / \mathrm{min}$. Three different elutes were obtained using three different ratios of ether: light petroleum mixture as mobile phase i.e. Elute 1 contained $6 \%$ of ether while elute 2 and 3 contained $15 \%$ and $50 \%$ of ether. Elutes obtained were transferred to a sample holder, and burned in a suitable combustion flask flushed with oxygen. The gases produced gets absorbed in a suitable solution in the combustion flask (water for chloride and $\mathrm{H}_{2} \mathrm{SO}_{4}$ in case of phosphate pesticides). For chloride pesticides, $15 \mathrm{~mL}$ of the solution obtained after combustion was mixed with $1 \mathrm{~mL}$ of ferric ammonium sulphate $(0.25 \mathrm{~mol} / \mathrm{L})$ and $3 \mathrm{~mL}$ of mercuric thiocyanate followed by swirling it where absorbance was measured at $460 \mathrm{~nm}$. For investigation of phosphate pesticides, $7 \mathrm{~mL}$ of the solution obtained after combustion was mixed with $2.2 \mathrm{~mL}$ of sulphuric acid $(300 \mathrm{~g} / \mathrm{L})$, $0.4 \mathrm{~mL}$ of ammonium molybdate $(40 \mathrm{~g} / \mathrm{L})$ and $0.4 \mathrm{~mL}$ of amino naphtha sulphonic acid followed by swirling it and heating it at $100^{\circ} \mathrm{C}$ for $12 \mathrm{~min}$ which was then measured at $820 \mathrm{~nm}$.

\section{Preparation of fruit extracts and preliminary phytochemical analysis}

Fresh fruits from $P$. pashia tree were plucked. Fruits were cut into quarters and were shade dried for 2 weeks at room temperature. Dried fruits were then coarsely ground to obtain homogenous powder using mechanical grinder. The homogenous powdered drug $(1.8 \mathrm{~kg})$ were extracted with $95 \%$ ethanol (4l) for three days by cold maceration process, $150 \mathrm{gms}$ of residue was obtained after removal of solvent at reduced pressure. The ethanolic extract of Pyrus pashia (EPP) obtained from cold maceration process was subjected to successive fractionation by liquid-liquid partition technique. The dried ethanolic root extract (150 g) was dissolved and suspended in aqueous medium which was later partitioned with solvent of increasing polarity such as hexane, chloroform, ethyl acetate and $n$-butanol. All the successive fractions obtained were filtered and concentrated under reduced pressure. The preliminary phytochemical screenings of the ethanolic extract from P. pashia (EPP) as well as its successive fractions were tested following the methods described by. ${ }^{27,28}$

\section{Determination of total polyphenols}

Total polyphenol content was determined spectrophotometrically with UV-Visible 1700 Shimadzu spectrophotometer, according to a modified method $^{29}$ using Folin-Ciocalteu's reagent. $100 \mu \mathrm{L}$ of ethanolic extract of Pyrus pashia (EPP) was taken in a $25 \mathrm{~mL}$ volumetric flask followed by addition of $500 \mu \mathrm{L}$ of Foilin Ciocalteu's reagent $(1 \mathrm{~N})$ and $1 \mathrm{~mL}$ of $30 \%$ sodium carbonate solution in it. Volume was made up to $25 \mathrm{ml}$ using distilled water followed by vigorous shaking. Solution was then left for incubation for $60 \mathrm{~min}$. The appearance of blue colour was measured spectrophotometrically at $730 \mathrm{~nm}$ against a sample blank. The total polyphenol content of EPP was calculated as gallic acid equivalent from the calibration curve of gallic acid standard solutions $(20,40,60,80,100 \mu \mathrm{L}$ 
aliquots of $0.1 \%$ aqueous gallic acid) and expressed as mg gallic acid equivalent (GAE)/gm of the EPP. All the measurements were done in triplicate.

\section{Determination of total flavonoids}

For the determination of total flavonoid content, the samples were measured using a modified colorimetric method..$^{30}(100 \mu \mathrm{L})$ of EPP was taken in $5 \mathrm{~mL}$ volumetric flasks followed by addition of $100 \mu \mathrm{L}$ of $10 \%$ aluminium chloride $(\mathrm{w} / \mathrm{v})$ and $100 \mu \mathrm{L}$ of $1 \mathrm{M}$ potassium acetate solution in it. Volume was then adjusted to $5 \mathrm{~mL}$ with distil water. Solution then forth was incubated at room temperature $\left(25^{\circ} \mathrm{C}\right)$ for $30 \mathrm{~min}$; the absorbance of the reaction mixture relative to blank was measured at $415 \mathrm{~nm}$. The total flavonoid content of samples was expressed as mg quercetin equivalent/gm of EPP. For the preparation of calibration curve 25, 50, 75, 100 and $125 \mu \mathrm{L}$ of standard quercetin in ratio of $(0.5 \mathrm{mg} / \mathrm{mL})$ were mixed with the same reagents as described above and after 30 minutes, the absorbance at $415 \mathrm{~nm}$ was measured for determination of total flavonoids. All measurements were done in triplicate.

\section{Quantification of Lupeol in P. pashia fruits by HPLC}

Fruits of P. pashia were standardized using Lupeol (Sigma-Aldrich, St. Louis, MO, USA) as a marker compound after confirming its presence through thin layer chromatography. EPP was used for lupeol quantification. The extract was filtered through a $0.45 \mu \mathrm{m}$ membrane filter (Millipore, Ahmedabad, India) before HPLC analysis. A Shimadzu HPLC system (Japan) with PDA detector was used to perform the following analysis, where separation was carried out with a Cosmosil $C_{18}$ column $(150 \times 4.6 \mathrm{~mm}$, $5 \mu \mathrm{m}$ particle). Mobile phase used for the analysis was acetonitrile: water with $0.1 \%$ acetic acid (94:6). Flow rate was kept at $0.7 \mathrm{ml} / \mathrm{min}$ with injection volume of $10 \mu \mathrm{l}$. Data was collected at wavelength $254 \mathrm{~nm}$.

\section{RESULTS}

\section{Macroscopic characteristics}

Fruit is a spherical berry. The size of the fruits varied from $1-2.5 \mathrm{~cm}$ in diameter. The surface of the fruit is dark greyish in color bearing numerous densely distributed white and yellow spots Figure 1B. The fruit consists of fine wide radiating carpel chambers with one or two seeds attached in axile placentum; Figure 1C (Table 1).

\section{Microscopic Characterstics}

Microscopy of the fruit revealed that fruit had fleshy thick pericarp. The pericarp was differentiated into epicarp and thick mesocarp which formed the major part of the fruit. The epidermis consisted of thin layer of tangentially stretched thick walled cells. Inner to the epidermis was a thick zone of about 10 layers of tabular thick walled cells with darkly stained cell inclusions Figure 2A. The epidermal layer and hypodermal layer of thick walled cells were $110 \mu \mathrm{m}$ thick. Mesocarp showed complex tissue system and was differentiated into outer, middle and inner zones. The outer zone consisted of thick continuous mass of brachysclereids alternating with narrow bands of parenchyma cells Figure 2(C, D). Sclereids were small polyhedral, isodiametric and compact they had very thick lignified walls narrow canal like simple pits and narrow lumen Figure 2D. Middle parenchymatous mesocarp, inner to the outer mesocarp included wide polygonal thin walled compact cells having dense dark tannin contents Figure (E, F). The middle mesocarp showed vascular strands Figure 2D. The inner mesocarp formed the border of capillary chambers, the bordering zone consisted of thick layer of sclereids as well as parenchyma cells. The partition septum of the fruit was thick and parenchymatous in nature. The cells had dense accumulation of tannins Figure 2G.
Seed of the fruit was flat and thin, dark in colour having smooth texture. It was flat on the upper side and slightly convex on the lower side Figure $3 \mathrm{~A}$. Seeds were $3 \mathrm{~mm}$ long and $1 \mathrm{~mm}$ thick, the cotyledon was flat and occupied the interior of the seed Figure 3B. The seed coat exhibited complex structure. It showed outer continuous, compact layer of palisade cells Figure 3B. Palisade cells were vertically oblong and had length and width of 70 and $25 \mu \mathrm{m}$ respectively. The inner part of the seed coat was differentiated into outer thick walled parenchyma cells and an inner zone which was also parenchymatous in nature. These two zones had fairly thick walled darkly stained cells. The middle zone comprised of thin walled polyhedral compact cells Figure 3 (C, D and E).

\section{Powder Characteristics}

The powder of $P$. pashia fruit exhibited following elements; thick masses of brachysclereids were seen scattered in the powder. Isodiametric, thick walled, lignified, solitary sclereides with several thin radiating pit canals were observed Figure 4A. Parenchyma cells, Figure $4 \mathrm{~B}$ which are thin walled along with dark inclusions are seen as compact masses. These parenchyma cells constitutes middle mesocarp region of $P$. pashia fruit. Some cells containing dark tannin component were also evident Figure 4C. Thick circular plates of cells were often observed in powder. These circular plates are $110 \mu \mathrm{m}$ in diameter and are compact clusters of brachysclereides attached on the seed surface. These sclereid masses are surrounded by radiating parenchyma cells of the epidermis Figure 4D. Calcium oxalate crystals are visible as bright prismatic bodies when viewed under polarized light under dark background; Figure 4E.

\section{Physico-chemical parameters}

Various physicochemical constants of the powdered crude drug Pyrus pashia were determined. Results are summarized in Table 2. Fluorescence characteristics of the powdered crude drug are depicted in Table 3. Analysis was carried out both in day light as well as under long U.V (365

\section{Table 1: Macroscopic characteristics of: P. pashia}

\begin{tabular}{ll}
\hline Parameters & Observations \\
\hline Color & $\begin{array}{l}\text { Dark greyish, bearing numerous yellow and white } \\
\text { dots on its skin surface. }\end{array}$ \\
Size (length/width) & $2-5 \mathrm{~cm} / 1-3 \mathrm{~cm}$ \\
Shape & Ovoid, oval \\
Taste & Sweet and astringent \\
\hline
\end{tabular}

Table 2: Physicochemical parameters of $P$ pashia fruit powder

\begin{tabular}{cc}
\hline Parameters & Results \\
\hline Foreign matter & Not more than $1.40 \pm 0.3(\% \mathrm{w} / \mathrm{w})$ \\
Loss on drying & Not more than $3.83 \pm 1.2(\% \mathrm{w} / \mathrm{w})$ \\
Total Ash & Not more than $9.50 \pm 0.50(\% \mathrm{w} / \mathrm{w})$ \\
Acid insoluble ash & Not more than $4.55 \pm 0.20(\% \mathrm{w} / \mathrm{w})$ \\
Water soluble ash & Not more than $1.29 \pm 0.15(\% \mathrm{w} / \mathrm{w})$ \\
Alcohol soluble extractive & Not less than $40.80 \pm 1.02(\% \mathrm{w} / \mathrm{w})$ \\
Water soluble extractive & Not less than $28.40 \pm 1.02(\% \mathrm{w} / \mathrm{w})$ \\
Foaming index & Less than 100 \\
Swelling index & $4.5 \pm 0.81$ \\
Volatile oil & Present \\
Crude fibre content & $12.860(\% \mathrm{w} / \mathrm{w})$ of plant material \\
Haemolytic index & $79.47 \pm 4.5 \mathrm{unit} / \mathrm{gm}$ \\
\hline
\end{tabular}


Table 3: Fluorescence powdered drug analysis of $P$. pashia fruits

\begin{tabular}{|c|c|c|c|}
\hline Powder+Reagent & $\begin{array}{c}\text { Fluorescence in } \\
\text { daylight }\end{array}$ & Fluorescence (254 nm) & Fluorescence (365 nm) \\
\hline Powder as such & Brown & NF & $\mathrm{NF}$ \\
\hline Powder $+1 \mathrm{~N} \mathrm{NaOH}$ in methanol & Dark red & NF & NF \\
\hline Powder $+1 \mathrm{~N} \mathrm{NaOH}$ in water & Dark red & NF & $\mathrm{NF}$ \\
\hline Powder $+1 \mathrm{~N} \mathrm{HCl}$ in methanol & Maroon & NF & Spring green \\
\hline Powder $+1 \mathrm{~N} \mathrm{HCl}$ in water & Gold & Wheat & Sea green \\
\hline Powder+1 $1 \mathrm{~N} \mathrm{HNO}_{3}$ in methanol & Dark red & NF & Yellow green \\
\hline Powder $+1 \mathrm{~N} \mathrm{HNO}_{3}$ in water & Orange & Golden rod & Lime green \\
\hline Powder+Iodine (5\%) & Orange red & NF & $\mathrm{NF}$ \\
\hline Powder $+\mathrm{FeCl}_{3}(5 \%)$ & Olive & NF & $\mathrm{NF}$ \\
\hline Powder+KOH (50\%) & Dark red & Golden rod & Sea green \\
\hline Powder+Ammonia (25\%) & Dark red & NF & Sea green \\
\hline Powder + Saturated Picric acid & Yellow & NF & $\mathrm{NF}$ \\
\hline Powder+Acetic acid & Orange & Aquamarine & Lime green \\
\hline
\end{tabular}

Table 4: Pesticide content analysis of: P. pashia

\begin{tabular}{cccc} 
Pesticide & First elute & Second elute & Third elute \\
\hline \multirow{2}{*}{ Chlorinated } & Not more than & Not more than 0.010 & Absent \\
& $0.021 \pm 0.002 \mathrm{mg} / \mathrm{kg}$ & $\pm 0.003 \mathrm{mg} / \mathrm{kg}$ & \\
Phosphated & Not more than & Not more than 0.015 & Absent \\
& $0.024 \pm 0.001 \mathrm{mg} / \mathrm{kg}$ & $\pm 0.005 \mathrm{mg} / \mathrm{kg}$ & \\
\hline
\end{tabular}

Table 5: Heavy Metal Analysis of: P. pashia

\begin{tabular}{cc}
\hline Heavy metals $($ conc in ppm) & Concentration $(\mathbf{p p m})$ \\
\hline Lead $(\mathrm{Pb})$ & Not more than $0.0065 \mathrm{ppm}$ \\
Cadmium $(\mathrm{Cd})$ & Not more than $0.00016 \mathrm{ppm}$ \\
Zinc $(\mathrm{Zn})$ & Not more than $0.1110 \mathrm{ppm}$ \\
Mercury $(\mathrm{Hg})$ & Not more than $0.1443 \mathrm{ppm}$ \\
\hline
\end{tabular}

$\mathrm{nm}$ ) and short U.V (254 nm). Colour identification was done using standard colour index chart.

\section{Pesticide content analysis}

Pesticide residue chlorinated as well as phosphated are summarised in Table 4 . The results obtained revealed the presence of chlorinated and phosphated pesticide residue which were found within permissible limits as prescribed by $\mathrm{WHO}$.

\section{Heavy Metal Analysis}

Concentration of various heavy metals such as lead, cadmium, zinc and mercury are summarized in Table 5. Results indicated that the values estimated were found to be within the limits as prescribed by the WHO guidelines.

\section{Preliminary phytochemical screening of EPP and its successive fractions}

The results from the phytochemical analysis of EPP and its successive fractions revealed the presence of flavonoids, phenols, carbohydrates, alkaloids, steroids and tannins as major constituents (Table 6).

\section{Total polyphenolic content in Ethanolic extract of Pyrus pashia}

The total polyphenol content of the EPP was measured spectrophotometrically against standard curve obtained by gallic acid. EPP contained $174.0 \mathrm{mg}$ of total polyphenols/gm of EPP measured as gallic acid equivalent.

\section{Total flavanoids content in Ethanolic extract of Pyrus pashia}

The total flavonoid content of the EPP was measured spectrophotometrically against standard curve obtained by quercetin. EPP contained $36.5 \mathrm{mg}$ of total polyphenols/gmof EPP measured as quercetin equivalent.

\section{Quantification of Lupeol in Ethanolic extract of P. pashia}

HPLC chromatogram of standard lupeol is represented in Figure 5. From the standard plot and linear line equation, the amount of lupeol in P. pashia extract was found to be $4.24 \% \mathrm{w} / \mathrm{w}$.

\section{DISCUSSION}

Quality control standardization of herbal drugs is an imperative step in correct identification and authentication of the plant material. Plants have been an integral part of pharmacotherapy throughout the history of mankind, and they have served as an invaluable source for the discovery of bioactive molecules since the very beginning of rational drug discovery in the 19th century. ${ }^{31-33}$ Hence, it is very essential to obtain a proper quality control profile for various medicinal plant used in traditional system of medicine. Prime step of all, the starting materials need to be correctly authenticated and should be freed from adulterants and contaminants. During plant growth, many factors like harvest season and time, developmental stage, temperature, and humidity have a strong impact on plant metabolite production. Also, postharvest processing steps which include drying and storage can significantly alter the phytochemical composition of herbal material. As the production of many phytopharmaceuticals includes an extraction step, extraction conditions and solvents need to be optimized in order to enrich the bioactive constituents of the extracts. The quality of finished preparations needs to be determined either on the basis of marker constituents or on the basis of analytical fingerprints. Thus, all production stages should be 
Hemalatha et al:: Pharmacognostical standardization of Pyruspashia fruits

Table 6: Preliminary phytochemical screening of EPP and its successive fractions of: P. pashia

\begin{tabular}{|c|c|c|c|c|c|c|}
\hline \multirow[b]{2}{*}{ Phytoconstituents } & \multirow{2}{*}{$\begin{array}{c}\text { Ethanolic } \\
\text { extract } \\
\text { (EPP) }\end{array}$} & \multicolumn{5}{|c|}{ EPP fractions } \\
\hline & & $\begin{array}{l}\text { Hexane } \\
\text { fraction }\end{array}$ & $\begin{array}{l}\mathrm{CHCl}_{3} \\
\text { fraction }\end{array}$ & $\begin{array}{l}\text { Ethyl acetate } \\
\text { fraction }\end{array}$ & $\begin{array}{l}\text { Butanol } \\
\text { fraction }\end{array}$ & $\begin{array}{l}\text { Aqueous } \\
\text { fraction }\end{array}$ \\
\hline Alkaloids & + & + & + & + & + & - \\
\hline Glycosides & - & - & - & - & - & + \\
\hline Coumarins & - & - & - & - & - & - \\
\hline Flavonoids & + & - & - & + & + & + \\
\hline Steroidal/triterpenes & + & + & + & & - & - \\
\hline Phenolic and tannins & + & - & + & + & + & + \\
\hline Saponins & + & - & - & - & - & + \\
\hline Mucilages & - & - & - & - & - & - \\
\hline Proteins & + & - & - & + & + & - \\
\hline Amino Acids & + & - & - & - & - & + \\
\hline Sugars & + & - & - & + & + & + \\
\hline
\end{tabular}


Figure 1: Macroscopy of Pyrus pashia fruits; A: Fruits of Pyrus pashia, B: Whole fruit exhibiting apical and stalk part of the fruit, C: TS of fruit showing epicarp, mesocarp, carpel chambers and seeds. (St: stalk of the fruit, AP: Apical part, Ep: Epicarp, MC: mesocarp).
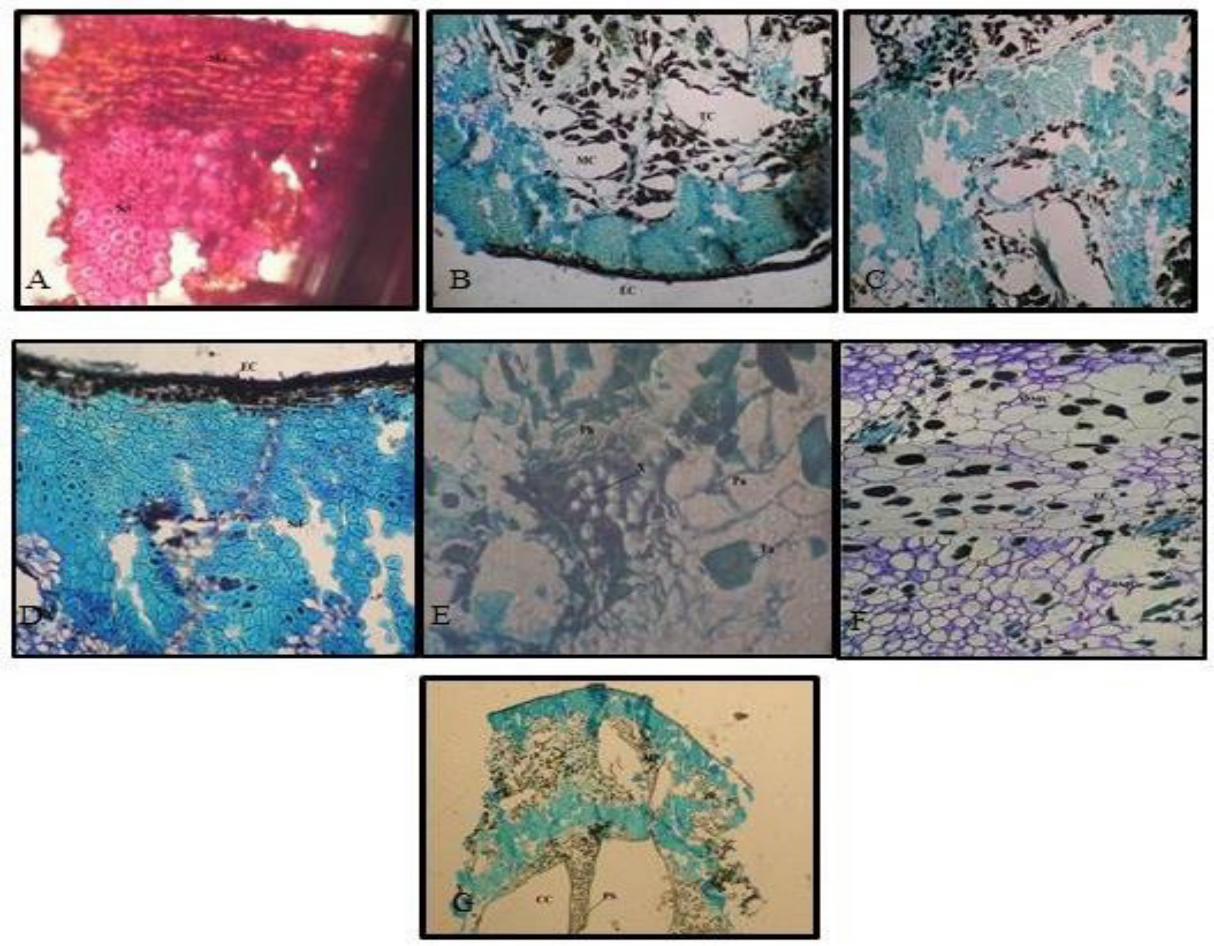

Figure 2: Microscopy of fruit: A:TS of the epicarp of fruit. B:TS of pericarp outer zone. C: TS of pericarp inner zone. D: Pericarp outer section. E: Vascular bundle in the pericarp. F: Parenchymatous region of the pericarp outer zone and inner zone. G: TS of the fruit showing outer pericarp and partition walls of carpel chamber. (Sec: sclerotic epicarp cells, Scl: sclereids, Tc: tannin cells, Mc: mesocarp cells, Ec: epidermal cells, Pa: parenchyma cells, Ph: phloem, X: xylem, OMC: outer mesocarp, IMC: inner mesocarp, CC: carpel chamber, PS: partition septum, MP: middle parenchyma. 

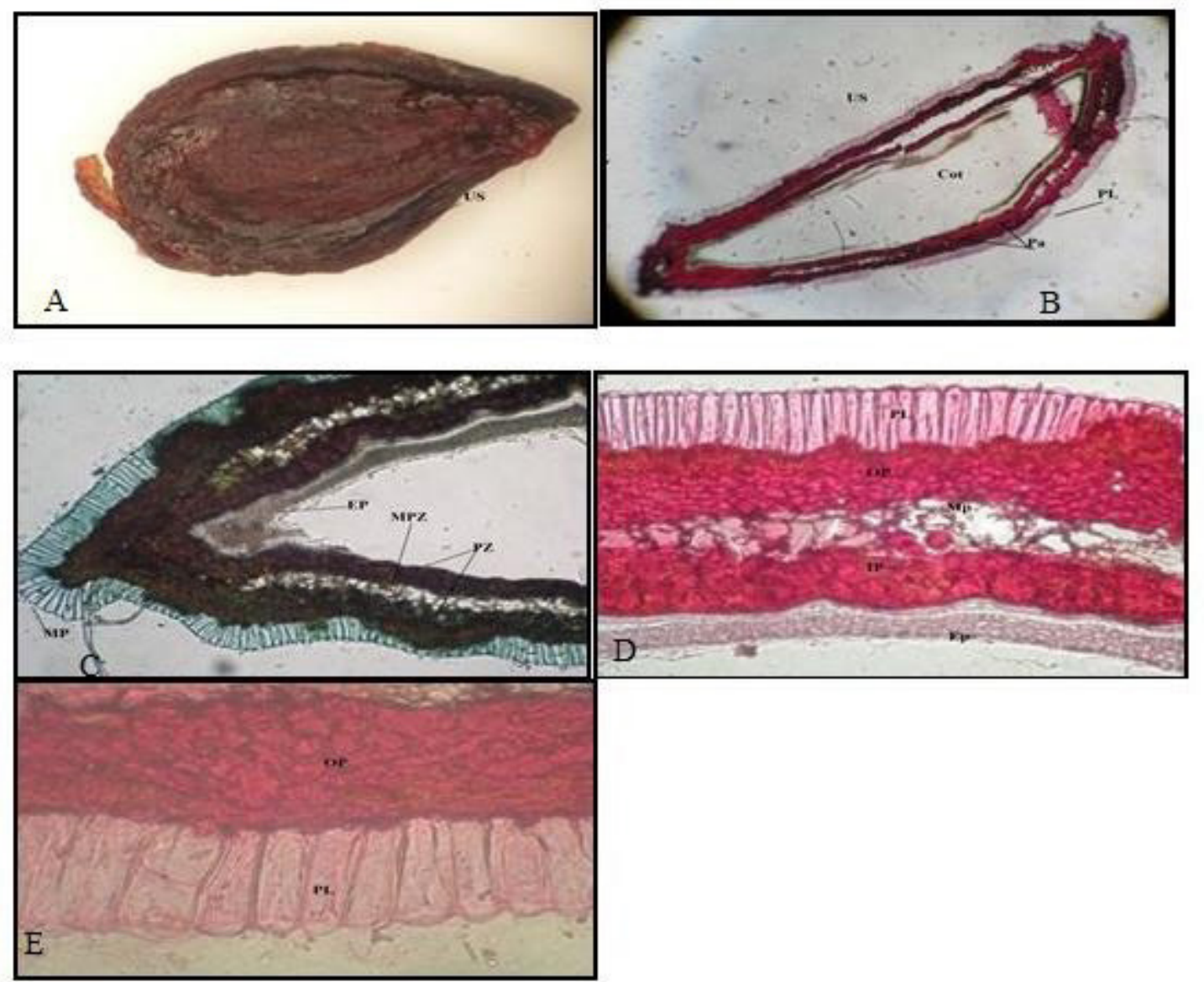

Figure 3: Microscopy of seed: A: Seed surface feature. B: Sectional view of seed. C: Longitudinal section of seed micropylar end. D: Mid part of seed wall. E: Sectional view of seed coat layers. (US: Upper side, Cot: Cotyledon, Pa: Parenchyma cells, PL: Palisade layer, Ep: Epidemis, MP: Micropylar end, PZ: Parenchyma zone, MPZ: Middle parenchyma zone, OP: Outer parenchyma zones, IP: Inner parenchyma zone, Mp: Middle parenchyma.
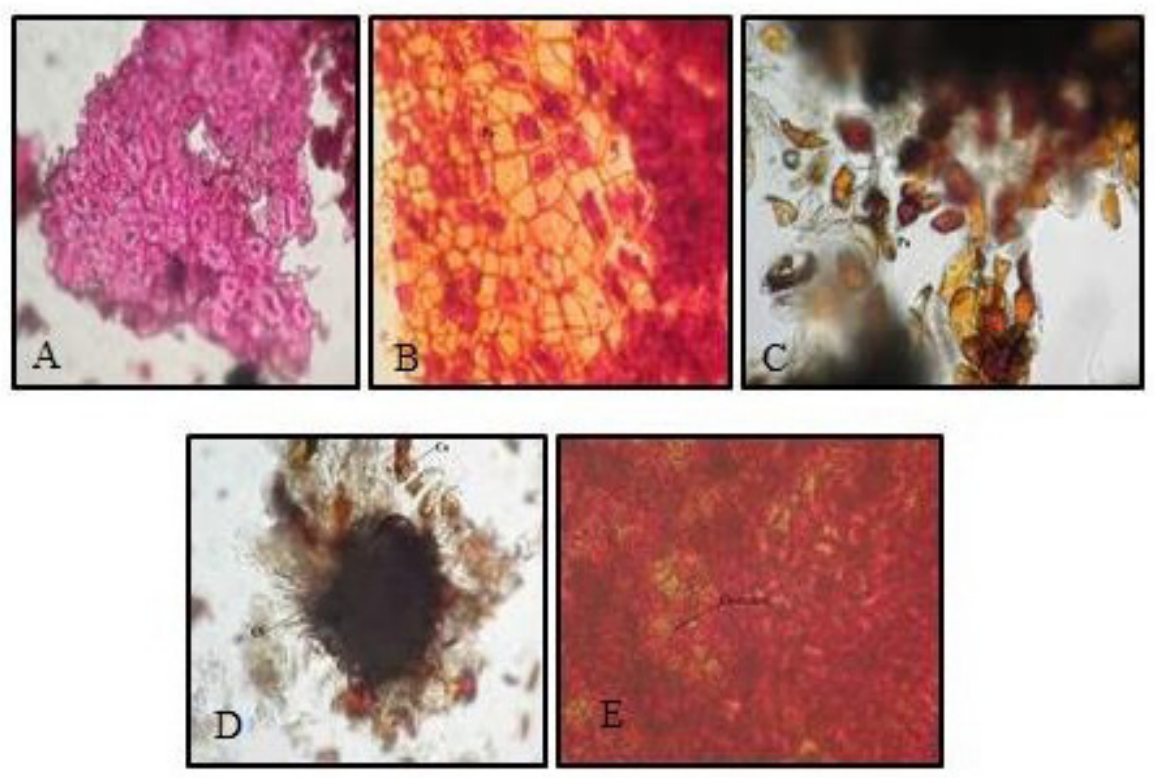

Figure 4: Powder characteristic of P. pashia fruit; A: Brachysclereids. B: Parenchymacells C: Parenchyma cells with tannin content. D: Circular plate of brachyslcereides. E: Calcium oxalate crystals viewed under polarized light. (Scl: Brachysclereids, Pa: parenchyma cells, Cs: circular spots. 

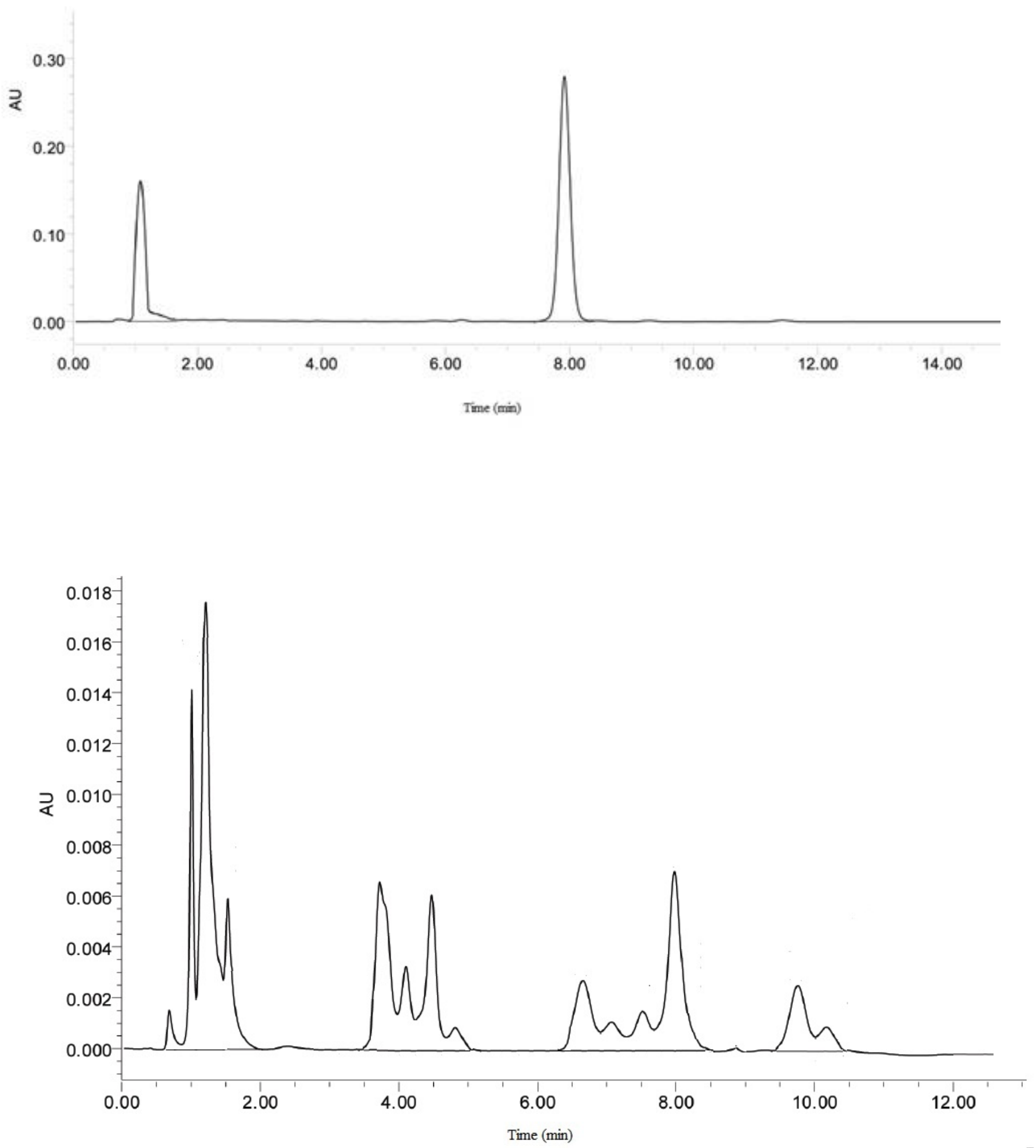

Figure 5: HPLC chromatogram of (A) standard Lupeol and (B) Ethanolic extract of Pyrus pashia. 
Hemalatha et al.: Pharmacognostical standardization of Pyruspashia fruits

accompanied by appropriate quality assessment measures. ${ }^{34}$ This may be helpful in minimizing the adulteration which occurs mainly due to improper knowledge regarding the varied geographical conditions, associated problems of different vernacular names, its morphology and microscopy. It is also said that correct identification and proper quality assurance of the starting materials is an essential prerequisite to ensure reproducible quality of herbal medicine which contributes to its safety and efficacy. ${ }^{35}$

Organoleptic analysis revealed that fruit is a thick berry bearing numerous densely distributed white spots. It is well known that the microscopical examination of crude drug aims at determination of the chemical nature of the cell wall along with the determination of the form and chemical nature of the cell contents. ${ }^{36}$ Thus, it determines the size, shape and relative structure of different cells and tissue in a plant drug. Microscopic analysis revealed that fruit has fleshy thick pericarp which is differentiated into epicarp and thick mesocarp, fruit is developed from pentacarpellary syncarpous ovary, and the mature fruit consists of wide radiating carpel chambers with one or two seeds attached on axile placentum. It is well established that the moisture is an inevitable component of crude drug, which must be eliminated as far as practicable. ${ }^{37}$ The extractive value determines the amount of active constituents in a given amount of medicinal plant material when extracted with the solvents. The extraction of any crude drug with a particular solvent yields a solution containing different phyto-constituents. The composition of these phyto-constituents in that particular solvent depends upon the nature of the drug and solvent used. Further, it is well established that the ash value is used to determine the quality and purity of drug. ${ }^{37}$ The ash of any organic material is composed of ash of their non-volatile inorganic components. Further, the controlled incineration of crude drug resulted in an ash residue consisting of an inorganic material (metallic salts and silica). This value varies within fairly wide limits and is therefore an important parameter for purpose of evaluation of crude drug. Thus on the basis of physiochemical constants various parameters were quantified which includes the amount of ash values, extractive value, foreign matter, loss on drying, swelling index, foaming index, haemolytic index etc. Furthermore, pesticide residue and heavy metals content were also assessed in the fruits of $P$. pashia However, the values estimated were found to be within the limits as prescribe by the WHO guidelines. ${ }^{2}$

Preliminary phytochemical screening revealed the presence of alkaloids, saponins, triterpenes, tannins, flavonoids, carbohydrates and sterols. Total phenolics and flavonoid analysis revealed that fruits of $P$. pashia are rich in phenolics and flavonoids. Phenolics are well established compounds for biochemical activities such as antioxidant, antimutagenic, anticarcinogenic, as well as have ability to modify the gene expression..$^{38,39}$ Moreover it has been reported that, certain phenols have been identified as potential neuroprotective compounds, aiming to one of the greater challenges in drug discovery today. ${ }^{40}$ Flavonoids in addition possess multifaceted beneficial bioactive qualities for health, such as antiallergic, anticancer, and anti-inflammatory activities, lowering blood pressure and plasma lipids and conferring cardioprotective and neuroprotective activities. ${ }^{41}$ HPLC is a versatile, robust, and widely used technique used in phytochemical and analytical chemistry for quantification, identification and purification of the mixture components. ${ }^{42}$ Moreover this technique is also useful for characterization and quantification of secondary metabolites in plant extract. ${ }^{43}$ HPLC studies revealed that concentration of lupeol in Pyrus pashia ethanolic exract was $4.24 \% \mathrm{w} / \mathrm{w}$.

P. pashia is a wild berry fruit from Himalayan region owning various traditional medicinal properties. Present study aims to standardize this wild edible fruit pharmacognostically and phytochemically, since natural products still remain as one of the best reservoirs of new drug moieties. Moreover standardization parameters evaluated can be beneficial for documentation and preparation of monograph.

\section{CONCLUSON}

The present study was undertaken to establish phamacognostic and phytochemical standardization of P.pashia to ensure the safety and quality of this ethnomedicinal plant.

\section{ACKNOWLEDGEMENT}

The authors wish to acknowledge Department of Pharmaceutics IIT (B.H.U) Varanasi for providing financial support to Ms Priyanka Sharma as Teaching Assistantship.

\section{CONFLICT OF INTEREST}

We declare that we have no conflict of interest.

\section{ABBREVIATION USED}

WHO: World Health Organization; BHU: Banaras Hindu University; CSIR: Council of scientific and Industrial Research; EPP: Ethanolic extract of Pyruspashia; TBA: Tertiary butyl alcohol; HPLC: High Performance Liquid chromatography.

\section{REFERENCES}

1. David B, Wolfender JL, Dias DA. The pharmaceutical industry and natura products: historical status and new trends. Phytochemistry Reviews. 2015 14(2):299-315

2. WHO." Quality Control Methods for Medicinal Plant Materials". Geneva: WHO; 2002.

3. Kumar D, Bhat ZA. Apigenin 7-glucoside from Stachys tibeticaVatke and its anxiolytic effect in rats. Phytomedicine. 2014;21(7):1010-4.

4. Pferschy-Wenzig EM., Bauer R. The relevance of pharmacognosy in pharmacological research on herbal medicinal products. Epilepsy and Behavior. 2015;52(Pt B):344-62.

5. Rakholiya K, Chanda S. Pharmacognostic, physicochemical and phytochemical investigation of Mangifera indica L. var. Kesar leaf. Asian Pacific Journal of Tropical Biomedicine. 2012;2(2):680-4.

6. Ghora C, Panigrahi G. The family Rosaceae in India. vol 2. Dehra Dun: India;1995

7. Sheikh MI. Trees of Pakistan. Pictorial Printers; 1993:110

8. Sharma P, Agnihotry A, Sharma PP, Sharma L. Wild edibles of Murari Devi and surrounding areas in Mandi district of Himachal Pradesh, India. International Journal. 2013;30(5):592-604.

9. Ambasta SP, Ramchandran K. The useful plants of India, publications and infor mation directorate. CSIR: New Delhi; 1986.

10. Sharma SK, Kumar N, Kumar H. Ethnobotanical studies on trees, shrubs and climbers of Himalaya. Satish Serial Publishing House; 2009.

11. Kumar M, Sheikh MA, Bussmann RW. Ethnomedicinal and ecological status of plants in Garhwal Himalaya, India. Journal of Ethnobiology and Ethnomedicine. $2011 ; 7(1): 1$.

12. Arya V, Gupta R, Gupta VK. Pharmacognostic and phytochemical investigations on PyruspashiaBuch.-Ham.ex D. Don stem bark. Journal of Chemical and Pharmaceutical Research. 2011;3(3):447-56.

13. Sawian JT, Jeeva S, Lyndem FG, Mishra BP, Laloo RC. Wild edible plants of Meghalaya, North-east India. Nat Prod Rad. 2007;6(5):410-26.

14. Khan MA, Khan MA, Hussain M, Ghulam GM. An ethnobotanical inventory of Himalayan region Poonch valley Azad Kashmir (Pakistan). Ethnobotany Research and Applications. 2010;8:107-23.

15. Saklani S, Chandra S. Phytochemical Screening of Garhwal Himalaya Wild Edible Fruit Ficuspalmata. International Journal of Pharm Tech Research. 2012;4(3):1185-91.

16. Gairola S, Sharma J, Bedi YS. A cross-cultural analysis of Jammu, Kashmir and Ladakh (India) medicinal plant use. Journal of Ethnopharmacology. 2014; 155(2):925-86

17. Abbasi AM, Khan MA, Ahmad M, Zafar M, Jahan S, Sultana S. Ethnopharmacological application of medicinal plants to cure skin diseases and in folk cosmetics among the tribal communities of North-West Frontier Province, Pakistan. Journal of Ethnopharmacology. 2010;128(2):322-35.

18. Abbasi AM, Khan MA, Khan N, Shah MH. Ethnobotanical survey of medicinally important wild edible fruits species used by tribal communities of Lesse Himalayas-Pakistan. Journal of Ethnopharmacology. 2013;148(2):528-36.

19. Gorsi MS, Miraj S. Ethnomedicinal survey of plants of Khanabad village and its allied areas, district Gilgit. Asian J Plant Sci. 2002;1(5):604-15.

20. Arya KR. Traditional uses of some common plants in indigenous folklore of Dronagiri; A mythic hill of Uttaranchal. Indian J Traditional Knowledge. 2002 $1(1): 81-6$. 
21. Johansen DA. Plant Microtechnique. McGraw Hill Publishers. New York, 182;1940.

22. O'brien TP, Feder N, McCully ME. Polychromatic staining of plant cell walls by toluidine blue O. Protoplasma. 1964;59(2):368-73.

23. Indian Herbal Pharmacopoeia. (Revised ed). Indian Drug Manufacturers;2002.

24. Chase CR, Pratt R. Fluorescence of powdered vegetable drugs with particular reference to development of a system of identification. Journal of the American Pharmaceutical Association. 1949;38(6):324-31.

25. Kokoski CJ, Kokoski RJ, Slama FJ. Fluorescence of powdered vegetable drugs under ultraviolet radiation. Journal of the American Pharmaceutical Association. 1958;47(10):715-7.

26. Gomez MR, Cerutti S, Sombra LL, Silva MF Martínez LD. Determination of heavy metals for the quality control in argentinian herbal medicines by ETAAS and ICP-OES. Food and Chemical Toxicology. 2007;45(6):1060-4.

27. Khandelwal KR. Practical pharmacognosy techniques and experiments. $17^{\text {th }}$ ed. Pune: Nirali prakashan. 2007:149-56

28. Harbone JB. Phytochemical Methods. $3^{\text {rd }}$ ed., London:Chapman and Hall publishers; 1984.

29. Sharma V, Kumar HV, Rao LJ. Influence of milk and sugar on antioxidant potentia of black tea. Food Research International. 2008;41(2):124-9.

30. Kosalec I, Bakmaz M, Pepeljnjak S, Vladimir-Knezevic SA. Quantitative analysis of the flavonoids in raw propolis from northern Croatia. Acta Pharmaceutica. 2004;54(1):65-72.

31. Sertürner FW. Über das Morphium, eine neue salz fähige Grundlage, und die Mekonsäure, als Hauptbestandteile des Opiums. Ann Phys. 1817;25:56-90

32. Kinghorn $A D$, Pan $L$, Fletcher JN, Chai $H$. The relevance of higher plants in lead compound discovery programs. Journal of Natural Products. 2011;74(6):1539-55.

33. Sneader W. Drug discovery: a history. Hoboken, N.J.: Wiley; 2005
34. Pferschy-Wenzig EM, Bauer R. The relevance of pharmacognosy in pharmacological research on herbal medicinal products. Epilepsy and Behavior. 2015;52(Pt B):344-362.

35. Nagani KV, Kevalia J, Chanda SV. Pharmacognostical and phytochemical evaluation of stem of Cissus quadrangularis L. International Journal of Pharmaceutical Sciences and Research. 2011;2(11):2856.

36. Ahire AE, Laddha KS, Pandit AB. Microscopical Examination of CarthamusTinctorius Linn. INDIAN DRUGS-BOMBAY. 2005;42(9):623.

37. Cho MH, Paik YS, Hahn TR. Enzymatic conversion of precarthamin to carthamin by a purified enzyme from the yellow petals of safflower. Journal of Agricultural and Food Chemistry. 2000;48(9):3917-21.

38. Nakamura Y, Watanabe S, Miyake N, Kohno H, Osawa T. Dihydrochalcones: evaluation as novel radical scavenging antioxidants. Journal of Agricultural and Food Chemistry. 2003;51(11):3309-12.

39. Tapiero H, Tew KD, Ba GN, Mathe G. Polyphenols: do they play a role in the prevention of human pathologies?. Biomedicine and Pharmacotherapy. 2002;56(4):200-7.

40. Loers G, Yashunsky DV, Nifantiev NE, Schachner M. Neural Cell Activation by Phenolic Compounds from the Siberian Larch (Larixsibirica). Journal of Natural Products. 2014;77(7):1554-15561.

41. Hwang SL, Shih PH, Yen GC. Neuroprotective effects of citrus flavonoids. Journal of Agricultural and Food chemistry. 2012;60 (4):877-885

42. Piana M, Zadra M, de Brum TF, Boligon AA, Gonçalves AF, da Cruz RC, et al. Analysis of Rutin in the Extract and Gel of Viola tricolor. Journal of Chromatographic Science. 2012;bms155.

43. Boligon AA, Agertt V, Janovik V, Cruz RC, Campos M, Guillaume D, Athayde ML, et al. Antimycobacterial activity of the fractions and compounds from Scutia buxifolia. Revista Brasileira de Farmacognosia. 2012;22(1):45-52.

\section{PICTORIAL ABSTRACT}



\section{SUMMARY}

- Microscopy of the Pyruspashia fruit showed typical characteristics of berry, having thick fleshy pericarp differentiated into thin epicarp and thick mesocarp having wide radiating carpel chambers with one or two seeds attached in axileplacentum

- Physiochemical analysis of powdered fruit powder such as Loss on drying, total ash, acid insoluble ash, water soluble ash, was found to be not more than $3.83 \pm 1.2(\% w / w), 9.50 \pm 0.50(\% w / w), 4.55 \pm 0.20(\% w / w), 1.29 \pm$ $0.15(\% \mathrm{w} / \mathrm{w})$, respectively. Whereas, alcohol and water soluble extractive values were not less than $40.80 \pm 1.02(\% \mathrm{w} / \mathrm{w})$ and $28.40 \pm 1.02(\% \mathrm{w} / \mathrm{w})$ respectively.

- Ethanolic extract of Pyruspashia (EPP) obtained from cold maceration and phytochemical screening of different fractions obtained by liquid partitioning revealed the presence of various secondary metabolites such as glycosides, steroids, triterpenoids, phenols, and flavonoids.

- The total phenolic content and total analysis revealed that fruits are rich source of phenols and flavonoid. The HPLC chromatogram suggested that EPP contained $4.24 \% \mathrm{w} / \mathrm{w}$ of lupeol.

\section{ABOUT AUTHORS}

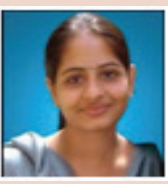

Priyanka Sharma: Is a PhD Research scholar in Department of Pharmaceutics Indian Institute of Technology, Banaras Hindu University. She is pursuing her PhD in Pharmacognosy. Her doctoral research is focussed on ethnopharmacological validation of plants used in neurological disorders as well as isolation of bioactive phytoconstituents.

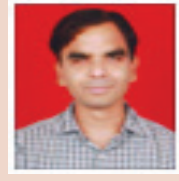

Dr. Satyendra K: Prasad is working as Assistant Professor in Pharmacognosy in Department of Pharmaceutical Sciences Rashtrakant Tukadoji Maharaj Nagpur University. He has number of papers published in national and international peer reviewed journals, 26 international and 5 national. Potential Dr. Satyendra is reviewer of peer reviewed journals such as: Journal of Ethnopharmacology, Pharmaceutical Biology, Medicinal Chemistry Research, Pharmacognosy Journal, Journal of Herbs Species and Medicinal Plants, Journal of Traditional and Complimentary Medicines.

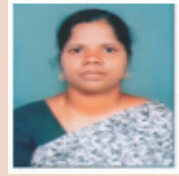

Dr. S. Hemalatha: Is working as Associate Professor in Pharmacognosy, Department of Pharmaceutics, Indian Institute of Technology (Banaras Hindu University), Varanasi. She has an experience of more than 18 years in the field of academics and research and published more than 100 research and review articles in International and National peer reviewed journals and has also co authored two books and one book chapter. She has supervised Ph.D and M.Pharm students and also successfully completed two projects sanctioned by the National Medicinal Plant Board (NMPB) and AICTE related to standardization of medicinal plants. She served as potential reviewer of various National and International journals. 